\title{
Occurrence Indicator
}

National Cancer Institute

\section{Source}

National Cancer Institute. Occurrence Indicator. NCI Thesaurus. Code C127786.

An indication as to whether something has happened, such as an event or intervention. 